\title{
An Assessment Of The Influence Of Syntagm And Context On Lexical Semantics In Translation Studies
}

\author{
Servais Martial Akpaca \\ ENSTIC, USTIM University, Republic Of Benin
}

\begin{abstract}
The Aim Of This Paper Is To Show That Words Only Have Meaning In Context. Dictionary Definitions Can Be Misleading Because In A Dictionary Words Are Listed In Isolation. However, To Contribute Meaning, Words Need To Be Used In Sentences Where They Contract Syntagmatic Relations With Other Words. Further, The Context In Which A Word Is Used Can Change Its Meaning. Different Contexts Can Activate Different Word Meanings. The Verb 'Consider', For Example, Has Taken Ten Different Meanings In The Examples Provided Below. As A Result, Word Meaning Is In The Field.
\end{abstract}

Key Words: Syntagm, Context, Lexicology, Lexical Semantics, Consider

\section{INTRODUCTION}

Like All Systematic Study Of The Formal Patterns Of Language, Lexicology Depends On Language Being Written Down (Halliday, 2004: 11). Many Oral Cultures Have Developed Highly Elaborated Theories Of Speech Function And Rhetoric, But It Is Only After Writing Evolves That Attention Comes To Be Focused On Grammar And Vocabulary. In India As Early As The Third To Second Century BC, Glossaries Were Drawn Up To Explain The Difficult Words In The Vedas, Which By That Time Were Already A Thousand Years Old. In China The Earlier Extant Lexicological Work Is In Fact A Thesaurus, The Er Ya 'Treasury Of Fine Words'. Compiled In This Form In The Third Century BC, It Is A List Of About 3,500 Words. (Ibid, 12)

In The Arab World, Lexicological Works Started Much Later. "The Earliest Arab Grammarian, Al-Khalil Ibn Ahmed (Died A.D. 791), Is Known To Have Begun Work On An Arabic Dictionary.” (Ibid)

Lexicological Works In Europe Started Towards The End Of The 15th Century. Dictionaries Were Developed To Promote Education And Literary Languages. The Development Of Dictionaries In The Modern European Context Was Associated With The Spread Of Education And The Promotion Of Emerging National Literary Languages. From About 1450 Onwards Bilingual Dictionaries Were Being Produced For Use In Schools, At First For Learning Latin (Latin-German, Latin-English, Etc.), But Soon Afterwards Also For The Modern Languages Of Europe. (Ibid)

With The Development Of Computers And Icts, Lexicological Work Has Assumed A New Dimension. This Paper Attempts To Demonstrate Through The Lexical Items 'Consider', 'Demand' And 'Industrial' That Word Meaning Is Determined By The Context In Which The Word Is Used. It Is Not Possible To Predict All The Meanings That A Word May Have Because It Is Only In A Context That Word Meaning Is Activated. Examples Of The Relationship Between Syntagm And Semantics Are Found In The TAUM/AVIATION Theory Developed By A Team Of Translators Of The University Of Montreal, Canada. The Point This Paper Is Making Is That The Idea That Words Have Specific Meanings Does Not Hold Water. When We Look Up A Word In A Dictionary, We Find That Its Senses Are Listed. However, This Listing Can Be Misleading Because Words Have Uses; They Do Not Have Meanings. A Mere Syntagm Can Influence The Meaning Of A Verb In A Sentence. In Much The Same Way, The Contextual Relations That A Verb Or A Noun Contracts With Other Words In A Sentence Can Also Influence Its Meaning. Therefore, The Belief That Words Have Meanings And That Dictionaries Contain The List Of The Various Senses Of Words Cannot Take Us Far. The Context In Which A Word Is Used Plays A Major Role In Determining Its Meaning.

\section{THE THEORETICAL FRAMEWORK OF THE PAPER}

This Paper Relies On Halliday To Recall The History Of Lexicology. Then, The Theories Developed By Patrick Hanks, Cruse, Trier, Monique Chevalier, Pierre Isabelle, François Labelle And Claude Lainé Are Used In This Paper On The Relationship Between Syntagm, Context And Semantics. Patrick Hanks Says That After Writing Dictionary Definitions For Over Thirty Years, He Has Come To Realise That Words Do Not Have Meanings. This Realisation Has Come About Thanks To The Development Of Corpora Available In Soft Copies. Cruse Also Contributes To The Debate By Highlighting The Role Of Context In Lexical Semantics. Words Contracts Contextual Relations With Other Words In A Sentence And Contribute New Meanings. Trier Says That Meaning Is In The Field. Monique Chevalier, Pierre Isabelle, François Labelle And Claude Lainé 
Shed Light On The Experience Of TAUM/AVIATION, A Machine Aided Translation System Used In Canada. The Instructions Given To The Machine By The Traductologue (Translation Analyst) Show Clearly That The Meanings Of Verbs Are Influenced By The Syntagms In Which They Are Used.

\section{III.1 What Is A Context?}

\section{DEFINITIONS}

Cruse Gives An Explanation Of The Notion Of Context In Contextual Approach To Lexical Semantics. It Is Assumed That The Semantic Properties Of A Lexical Item Are Fully Reflected In Appropriate Aspects Of The Relations It Contracts With Actual And Potential Contexts. In Theory, The Relevant Contexts Could Include Extra-Linguistic Situational Contexts. But There Are Good Reasons For A Principled Limitation To Linguistic Contexts: First, The Relation Between A Lexical Item And Extra-Linguistic Contexts Is Often Crucially Mediated By The Purely Linguistic Contexts (Consider The Possible Relations Between Horse And The Extra-Linguistic Situation In That's A Horse And There Are No Horses Here) ; Second, Any Aspect Of An Extra-Linguistic Context Can In Principle Be Mirrored Linguistically; And Third, Linguistic Context Is More Easily Controlled And Manipulated. Cruse (1986: 1)

It Emerges From This Quotation That The Various Senses Of A Lexical Item Are Reflected In Various Situations. Each Situation Sheds Light On A Particular Aspect Of A Word Meaning. Lexical Items Have Semantic Properties That Are Reflected In Contexts. Various Sentences Can Present Various Aspects Of The Meaning Of A Word. Sometimes Some Particular Words Refer To Extra-Linguistic Realities. However, These Realities Can Be Reflected And Revealed In Linguistic Contexts.

Patrick Hanks Has Also Made A Contribution To This Discussion In A Paper Titled 'Do Word Meanings Exist ?'My Contribution To This Discussion Is To Attempt To Spread A Little Radical Doubt. Since I Have Spent Over 30 Years Of My Life Writing And Editing Monolingual Dictionary Definitions, It May Seem Rather Odd That I Should Be Asking, Do Word Meanings Exist? The Question Is Genuine, Though: Prompted By Some Puzzling Facts About The Data That Is Now Available In The Form Of Machine-Readable Corpora. I Am Not The Only Lexicographer To Be Asking This Question After Studying Corpus Evidence. Sue Atkins, For Example, Has Said 'I Don't Believe In Word Meanings' (Cited As The Title Of A Paper By Kilgarriff, $1997^{\mathrm{e}}$ ), And Eugene Nida (1997) Is One Of Many Who Have Insisted That Words Only Have Meaning In Context. Patrick H. (2000)

To Buttress These Ideas, The Following Sentence Is Given: 'I Went To The Bank.' There Is No Indication In This Sentence As To Whether Bank Refers To A Financial Institution Or To A River. Only The Context In Which This Sentence Is Uttered Can Help To Disambiguate It.

It Is Worth Pointing Out That In This Era Of Information Technology, Word Meaning Should Be Regarded As Dynamic And Progressive Rather Than Static And Fixed. The Point Is That Every Day Words Are Used In Various Fields As Knowledge About Scientific And Technological Areas Expands. In This Context, It Is An Illusion To Believe That Word Meaning Never Changes.

\section{III.2 Lexical Semantics}

'Semantics Is The Study Of Meaning Communicated Through Language... It Is The Study Of The Meanings Of Words And Sentences.' (Saeed, 2009: 3) Lexical Semantics Is About Word Meaning. M.A.K. Halliday Makes The Following Point In Lexicology And Corpus Linguistics (2004: 2-3):

If We Are Using The Term 'Word' To Mean A Unit Of The Written Language, I.E. 'That Which (In English) Is Written Between Two Spaces', Then Ultimately All These Choices Are Expressed As Strings Of Words, Or Wordings, As In It Always Snows On Top Of The Mountain. But Teachers Of English Have Customarily Distinguished Between Content Words, Like Snow And Mountain, And Function Words, Like It And On And Of And The; And It Is The Notion Of A Content Word That Corresponds To Our Lexical Item. Lexicology Is The Study Of Content Words, Or Lexical Items. This Is An Important Point Because It Makes A Distinction Between Content Words And Function Words. We All Know What A Mountain Is And We Can Describe It. On The Contrary, Function Words Have No Content That Can Be Described. However, It May Be A Hasty Conclusion To Say That Lexicology Is Only About The Study Of Content Words. The Relationship Between Function Words And Lexicology Is Not Non-Existent. Examples Of Relationship Between Function Words And Lexical Semantics Are Given In The TAUM/AVIATION Algorythm That Will Be Shown At A Later Stage. III.3 What Is Lexicology? As Indicated Above, Halliday (Ibid, 3-4) Says That Lexicology Is The Study Of Content Words. However, The Line Between Content Words And Function Words Is Not A Sharp One. Rather, The Two Form A Continuum Or Cline, And Words Like Always And Top Lie Somewhere Along The Middle Of The Cline. ' Thus There Is No Exact Point Where The Lexicologist Stops And The Grammarian Takes Over; Each One Can Readily Enter Into The Territory Of The Other.' The Author Explains That There Are Two Principal Methods For Describing Words, Though The Two Can Also Be Combined In Various Ways. One Method Is By Writing A Dictionary; The Other Is By Writing A Thesaurus. The Difference Between A 
Dictionary And A Thesaurus Is This. In A Thesaurus, Words That Are Similar In Meaning Are Grouped Together: So, For Example, All Words That Are Species Of Fish, Or All Words For The Emotions, Or All The Words To Do With Building A House. In A Dictionary, On The Other Hand, Words Are Arranged Simply Where You Can Find Them (In Alphabetical Order In English). IV. The Relationship Between Syntagm And Semantics IV.1 TAUM/AVIATION And TAUM/METEO In MontrealIn Meta (1981: 35) Chevalier, Isabelle And Others Describe The Job That A 'Traductologue,l (Analyst Of Translation) Does. A Team Of The University Of Montreal Has Developed The TAUM/METEO And The TAUM/AVIATION Systems Of (Machine Aided) Translation. The METEO System Helps To Translate Weather Bulletins, While The AVIATION System Translates Information On The Maintenance Of An Aircraft Manufactured In Canada. These Systems Follow The Instructions Given By An Expert Called 'Traductologue'. The Term Traductologue Comes From Traductologie, A Term Coined By B. Harris (1973). Other Authors Have Given Different Names To This Scientific Activity. Mounin (1963) And Catford (1965) Talk About A Linguistic Theory Of Translation. Nida (1964) Speaks Of A Science Of Translation. Vinay And Darbelnet (1958) Use The Term «Stylistique Comparée ».

Some Examples Of Instructions Given By The Traductologue Are Given Below.

Preparing The Computer For The Translation Process:

The Following Sentence Is To Be Translated Into French:

(1) The $\{$ Tank $\} \quad$ Should Be Serviced By Personnel.

The $\{$ Aircraft $\} \quad$ Should Be Serviced By Personnel.

Le Verbe 'Service’ Peut Se Traduire Par «Remplir» Ou Par «Faire L'entretien De » Selon Que Son Objet Direct Désigne Ou Non Un Contenant. (Ibid, 37)

In This Example Of Instruction, The Meaning Of The Verb Service Is Influenced By Its Direct Object. The Traductologue Tells The Computer That The Verb Of This Sentence Is Service, While The Subject Is Personnel And The Direct Object Is Tank Or Aircraft. If 'Tank' Is The Direct Object, The Verb Service Can Only Be Translated By Remplir. If 'Aircraft' Is The Direct Object, The Verb Service Can Only Be Translated By Faire L'entretien De. 'La Nature Sémantique De L'objet Direct De 'Service' Est Un Facteur Pertinent Pour La Traduction De Ce Verbe." (Ibid)

The Instructions Proceed As Follows:

S'il Y A Un Objet Indirect Introduit Par With, Traduire Service Par Mettre.

Ex: A) Service Tank With One Gallon Of Oil.

B) Mettre Un Gallon D’huile Dans Le Réservoir. (Ibid, 39)

Further Instructions Given To The Machine Lead To The Following Translations: (Table 1)

\begin{tabular}{|c|c|}
\hline $\begin{array}{l}\text { (6) Consider The Damage As } \\
\text { Extending To The Wing Tip. }\end{array}$ & $\begin{array}{l}\text { (6F) Supposer Que Les Dommages } \\
\text { S'étendent Jusqu'au Saumon D'aile. }\end{array}$ \\
\hline $\begin{array}{l}\text { (7) Accuracy Is Considered As The } \\
\text { Most Important Criterion. }\end{array}$ & $\begin{array}{l}\text { (7F) La Précision Est Considérée } \\
\text { Comme Le Critère Le Plus Important. }\end{array}$ \\
\hline (8) Consider These Areas For Repair. & $\begin{array}{l}\text { (8F) Envisager La Réparation De Ces } \\
\text { Zones. }\end{array}$ \\
\hline $\begin{array}{l}\text { (9) Consider Whether The Damage Is } \\
\text { Negligible. }\end{array}$ & $\begin{array}{l}\text { (9) Déterminer Si Les Dommages Sont } \\
\text { Négligeables. }\end{array}$ \\
\hline (10) Consider Cleaning The Filter. & (10F) Penser A Nettoyer Le Filtre. \\
\hline $\begin{array}{l}\text { (11) The System Is Considered } \\
\text { Serviceable. }\end{array}$ & $\begin{array}{l}\text { (11F) On Peut Considérer Que Le } \\
\text { Circuit Est Utilisable. }\end{array}$ \\
\hline $\begin{array}{l}\text { (12) Consider The Damage To Extend } \\
\text { To The Wing Tip. }\end{array}$ & $\begin{array}{l}\text { (12F) Supposer Que Les Dommages } \\
\text { S'étendent Jusqu'au Saumon D'aile. }\end{array}$ \\
\hline $\begin{array}{llll}\text { (13) Consider That } & \text { Any Increase } & \text { In } \\
\text { Turbine RPM } & \text { Results } & \text { In } \\
\text { Overtemperature. } & & \end{array}$ & $\begin{array}{l}\text { (13F) Supposer Que Toute } \\
\text { Augmentation Dans Le Régime De La } \\
\text { Turbine Entraîne Une Surchauffe. }\end{array}$ \\
\hline
\end{tabular}

\footnotetext{
${ }^{1}$ This term was coined by B. Harris in « La traductologie, la traduction naturelle, la traduction automatique et la sémantique ", in Cahier de linguistique $n^{\circ} 2$ Les Presses de l’Université du Québec, Montreal, 1973. 


\begin{tabular}{|l|l|}
\hline $\begin{array}{l}\text { (14) Consider The Direction Of } \\
\text { Prevailing Winds. }\end{array}$ & $\begin{array}{l}\text { (14F) Tenir Compte De La Direction } \\
\text { Des Vents Dominants. }\end{array}$ \\
\hline $\begin{array}{l}\text { (15) Consider Each Cylinder To Make } \\
\begin{array}{l}\text { Sure Scratches Are Negligible. (Op. } \\
\text { Cit., 40) }\end{array}\end{array}$ & $\begin{array}{l}\text { (15F) Examiner Chaque Cylindre Pour } \\
\text { S'assurer Que Les Eraflures Sont } \\
\text { Négligeables. }\end{array}$ \\
\hline
\end{tabular}

Below Are Some Of The Instructions:

1. Si L'objet Indirect De Consider Est Une Proposition Gérondive Introduite Par As, Traduire Consider Par «Supposer Que " Et Transformer L'objet Direct De Consider (Damage) En Sujet De La Gérondive (Extend).

(6A) Consider The Damage As Extending To The Wing Tip.

(6F) Supposer Que Les Dommages S'étendent Jusqu'au Saumon D'aile.

2. Si L'objet Indirect Est Un Groupe Nominal, Il Peut Etre Introduit Par As Ou For :

(a) Si Le Groupe Nominal Est Introduit Par As, Traduire Consider Par « Considérer » :

(7A) Accuracy Is Considered As The Most Important Criterion.

(7F) La Précision Est Considérée Comme Le Critère Le Plus Important.

B) Si Le Groupe Nominal Est Introduit Par For, Traduire Par "Envisager », Effacer For ; Transformer L'objet Direct (Areas) En Complément De L'objet Indirect (Repair) ; Enfin, Déplacer L'objet Indirect En Objet Direct :

(8A) Consider These Areas For Repair.

(8F) Envisager La Réparation De Ces Zones. (Op. Cit.: 41)

On The Basis Of This Algorythm (Series Of Instructions) The Meaning Of The Verb 'Consider' Has Changed Ten Times. The Team Of Canadian Translators Says That The Various Uses Of The Verb 'Consider' Have Been Found In The Maintenance Manuals.

Cette Formalisation Du Verbe Consider Représente Les Différents Usages De Ce Mot Que Nous Avons Recensés Dans Les Manuels D’hydraulique. Les Phrases (6) A (15) Font Donc Partie De La Classe De Phrases Décrites Par La Complémentation Du Verbe Consider. (Ibid, 40)

In The Above-Mentioned Algorythm, The Following Instruction Is Given And Shows That The Meaning Of The Verb 'Consider' Is Influenced By The Preposition With. 'S'il Y A Un Objet Indirect Introduit Par With, Traduire Service Par Mettre.,

Just Like The Verb 'Consider', The Lexical Items 'Demand' And 'Industrial' Take Several Meanings In The Various Contexts In Which They Are Used In The Materials Upon Which This Study Has Been Carried Out. They Illustrate The Point That The Meaning Of A Word Is Based On The Context In Which It Appears.

IV.2 A Study Of Various Occurrences Of The Words 'Demand' And 'Industrial'

Let Us Now Look Up The Words 'Industrial' And 'Demand' In A Modern English Language Dictionary Before Any Attempt To Study The Various Occurrences Of The Same In The Corpus (Made Up Of Trade Union Literature).

What Do The Words 'Industrial' And 'Demand' Mean?

According To The Oxford Advanced Learner's Dictionary, The Word 'Industrial' Means [1] Connected With Industry: Industrial Conflict/Disputes/Unrest - Industrial Development/Production/Output - An Industrial Accident [2] Used By Industries: Industrial Chemicals - Industrial Strength [3] Having Many Industries: An Industrial Area/Town - An Industrial Society/Economy.

The Dictionary Also Contains Entries Such As Industrial Action, Industrial Archeology, Industrial Arts, Industrial Estate, Industrial Relations, Industrial Revolution And Industrial Tribunal.

The Word 'Demand' Means [1] A Very Firm Request For Something; Something That Somebody Needs: A Demand For Higher Pay [2] Demands (Pl.) - (Of Sth) - (On Sb) Things That Sb/Sth Makes You Do, Especially Things That Are Difficult, Make You Tired, Worried, Etc. Flying Makes Enormous Demands On Pilots. [3] (For Sth/Sb) The Desire Or Need Of Customers For Goods Or Services Which They Want To Buy Or Use: To Meet The Demand For A Product. The Occurrences Of These Words And Their Equivalents In The French Language Have Been Found In Different Contexts In The Trade Union Literature. A Few Examples Are Given Below: (Table 2)

\begin{tabular}{|l|l|}
\hline We Continue To Collect Evidence Of & Nous Continuons De Recueillir Des \\
Violations Against Workers' Rights And & Informations Sur Les Violations Contre \\
To & Les Droits \\
Demand Accountability From Abusive & Des Travailleurs Et D'exiger Que Les \\
Governments And Employers. (P.9) & Gouvernements Et Les Employeurs Aux \\
\hline
\end{tabular}




\begin{tabular}{|c|c|}
\hline & $\begin{array}{l}\text { Pratiques } \\
\text { Peu Scrupuleuses Soient Tenus De } \\
\text { Rendre Des Comptes. (P.9) }\end{array}$ \\
\hline $\begin{array}{l}\text { The Five Officials Were Handed } \\
\text { Summary Dismissal Letters Following } \\
\text { The Strike That Took Place At The } \\
\text { Company In April To Demand Fair } \\
\text { Working Conditions. (P.55) }\end{array}$ & $\begin{array}{l}\text { Les Cinq Responsables Ont Reçu Des } \\
\text { Lettres De Renvoi Sans Préavis Dans La } \\
\text { Foulée De La Grève Qui A Eu Lieu Dans } \\
\text { L'entreprise En Avril Pour Réclamer } \\
\text { Des Conditions De Travail Equitables. } \\
\text { (P.57) }\end{array}$ \\
\hline $\begin{array}{l}\text { The Workers' Main Demand Is For The } \\
\text { Company To Comply With ILO } \\
\text { Convention } 87 \text { And Respect Their } \\
\text { Decision To Join The Mexican Miners' } \\
\text { And Metalworkers' Union } \\
\text { (SNTMMSRM). (P.63) }\end{array}$ & $\begin{array}{l}\text { La Principale Revendication Des } \\
\text { Travailleurs Portait Sur Le Respect Par } \\
\text { L'entreprise De La Convention 87 De } \\
\text { L'oit Et De Leur Décision D'adhérer Au } \\
\text { Syndicat Mexicain Des Mineurs Et Des } \\
\text { Métallurgistes NTMMSRM. (P.67) }\end{array}$ \\
\hline $\begin{array}{l}\text { Protesting Police Baton Charged: On } 19 \\
\text { March 2015, Dozens Of Under-Training } \\
\text { Assistant Sub-Inspectors (Asis) And } \\
\text { Head Constables Of The Sindh Police } \\
\text { Were Subjected To Baton } \\
\text { Charge And Arrests After They } \\
\text { Protested Outside The Central Police } \\
\text { Office On II Chundrigar Road To } \\
\text { Demand Payment Of } \\
\text { Salaries Pending For The Past Few } \\
\text { Months. (P.76) }\end{array}$ & $\begin{array}{l}\text { Manifestation De La Police Réprimée A } \\
\text { La Matraque: Le 19 Mars 2015, } \\
\text { Plusieurs Dizaines De Sous-Inspecteurs } \\
\text { Assistants } \\
\text { En Formation Ainsi Que Des Agents } \\
\text { Grades Des Forces De Police De La } \\
\text { Province De Sindh Ont Eté Attaqués A } \\
\text { La Matraque Et Arrêtés Après Avoir } \\
\text { Manifeste Devant Le Bureau Central De } \\
\text { La Police, Au II Chundrigar Road, Pour } \\
\text { Demander Le Paiement De Leurs } \\
\text { Salaires, Qui N'avaient Pas Eté Verses } \\
\text { Depuis Plusieurs Mois. (P.79) }\end{array}$ \\
\hline $\begin{array}{l}\text { He Was Convicted For Distributing } \\
\text { CNDDC Leaflets Calling For A Peaceful } \\
\text { Sit-In Protest To Demand The Right To } \\
\text { Work That The Authorities Deemed } \\
\text { "Likely To Undermine National } \\
\text { Interest." (P.90) } \\
\text { No Further Progress Was Made For The } \\
\text { Remaining Four, And On } 19 \text { June } 2014 \\
\text { Two Of } \\
\text { Them Resorted To Going On Hunger } \\
\text { Strike To Demand Their Rights, } \\
\text { Including The UGTT Delegate Sonia } \\
\text { Jebali. (P.95) }\end{array}$ & $\begin{array}{l}\text { La Cour D'appel De Ouargla Avait } \\
\text { Condamné Un Autre Membre Du } \\
\text { CNDDC Parce Qu'il Avait Distribué Des } \\
\text { Prospectus Du CNDDC } \\
\text { Appelant A Un Sit-In Pacifique Pour } \\
\text { Défendre Le Droit Au Travail, Ce Que } \\
\text { Les Autorités Ont Qualifié D'action } \\
\text { «Susceptible De Nuire A L'intérêt } \\
\text { National». (P.96) } \\
\text { Aucune Action Supplémentaire N'a Eté } \\
\text { Entreprise Pour Les Quatre Autres } \\
\text { Travailleurs/Euses Et, Le 19 Juin 2014, } \\
\text { Deux D'entre Eux/Elles Ont Entamé Une } \\
\text { Grève De La Faim Pour Faire Valoir } \\
\text { Leurs Droits, Dont La Déléguée De } \\
\text { L'ugtt Sonia Jebali. (P.102) }\end{array}$ \\
\hline $\begin{array}{l}\text { The Situation Reached A Head On } 4 \\
\text { November } 2014 \text { With The Termination } \\
\text { Of } 19 \text { Union } \\
\text { Members' Contracts, Mostly Founding } \\
\text { Members, Due To The "Reorganisation } \\
\text { And Lower Demand During The Winter } \\
\text { Schedule. (P.83) }\end{array}$ & $\begin{array}{l}\text { La Situation A Atteint Un Point Critique } \\
\text { Le } 4 \text { Novembre 2014, Avec La } \\
\text { Résiliation Des Contrats De } 19 \\
\text { Employés Affilies Au Syndicat, Des } \\
\text { Membres Fondateurs Pour } \\
\text { La Plupart. Motif Invoques : } \quad \ll \\
\text { Restructuration Et Baisse De La } \\
\text { Demande Durant La Saison D'hiver } \gg . \\
\text { (P.88-89) }\end{array}$ \\
\hline
\end{tabular}

It Is Important To Stress That The Verb 'To Demand' Is Quite Often Translated Into French By Most Of The Verbs (Demander, Réclamer, Revendiquer, Exiger) Used In The French Text, Except For Faire Valoir And Défendre. Collins Robert French Dictionary Explains The Verb 'To Demand' As Follows: Money, Explanation, Help Exiger, Réclamer (From, Of De) ; Higher Pay Etc Revendiquer, Réclamer. To Demand To Do Exiger De Faire, Demander Expressément A Faire. A Question/Situation That Demands Our Attention Une 
Question/Une Situation Qui Réclame Notre Attention. It Is Clear That There Is A Good Number Of Equivalents Of The Verb 'To Demand' In The Various Contexts In Which It Is Used In The Table Above. Faire Valoir And Défendre May Find Their Way Into A Bilingual Dictionary As Equivalents Of The Verb 'To Demand' If They Are Used Again And Again By Translators. Lexicological Work Focuses On The Various Uses Of Lexical Items In Various Contexts. In The Table Above, Two Senses Of The Lexical Item 'Demand' Are Used. The Allusions To "Workers Demanding Their Rights And Fair Working Conditions" Refer To One Sense Of The Verb, Whereas The Reference To ''Lower Demand During The Winter' Is Another Sense Of The Word. There Is Another Aspect Of Lexicology In The Translation Of The Word 'Demand'. The Following Is A Context In Which The Word Is Used: “'.. To Demand Payment Of Salaries'” : Demander Le Paiement Des Salaires. Not All The French Verbs Used In The Table To Translate The Verb 'To Demand' Are Interchangeable. For Example, We Cannot Say 'Faire Valoir Le Paiement Des Salaires' But 'Réclamer Le Paiement Des Salaires' Is Acceptable; 'Exiger Le Paiement Des Salaires' Is Also Acceptable. The Partial Conclusion That Can Be Drawn Is That Faire Valoir Is An Equivalent Of The Verb To Demand In Some Specific Contexts. It Shares Some Semantic Properties With The Verb 'To Demand'.

The Following Syntagm Is Another Context In Which The Word 'Demand' Is Used: ' To Demand Fair Working Conditions"' : Réclamer Des Conditions De Travail Equitables. It Is Not Acceptable To Say: Défendre Des Conditions De Travail Equitables. In This Particular Context, Réclamer And Défendre Are Not Interchangeable. However, They May Be Interchangeable In Other Contexts. This Possibility Cannot Be Ruled Out. In Conclusion, Though The Verb 'To Demand' Is Translated Into French By Five Equivalents In The Table Above, Not All The Equivalents Are Interchangeable. Consequently, Only The Context Determines Which Equivalent Is Suitable. This Confirms The Idea That It Is Only In Context That Words Have Meanings.

This Conclusion Is Now Going To Be Tested With Another Lexical Item (I.E. 'Industrial') That Is

Quite Often Found In Documents Related To Labour. The Word Is Used In The Contexts Presented In The

Table Below. Table 3

\begin{tabular}{|c|c|}
\hline $\begin{array}{l}\text { In Malaysia, The Industrial Court Was Left } \\
\text { Vacant In August 2014when Four Judges } \\
\text { Retired At The Same Time, Further } \\
\text { Restricting The Already Limited Access To } \\
\text { Justice For Workers. (P.8) }\end{array}$ & $\begin{array}{l}\text { Travail Est Reste Vacant En Aout 2014, } \\
\text { Car Quatre Juges Ont Pris Leur Retraite En } \\
\text { Même Temps, Ce Qui A Limite Un Accès } \\
\text { A La Justice Déjà Restreint Pour } \\
\text { Les Travailleurs. (P.8) }\end{array}$ \\
\hline $\begin{array}{l}\text { Workers At The National Industrial And } \\
\text { Mining Company Went On Strike On } 28 \\
\text { January 2015 To Demand That The } \\
\text { Company Honour Pay Rises Agreed On } 3 \\
\text { May 2014. }\end{array}$ & $\begin{array}{l}\text { Les Travailleurs De La Société Nationale } \\
\text { Industrielle Et Minière (SNIM) Se Sont } \\
\text { Mis En Grève Le } 28 \text { Janvier } 2015 \text { Pour } \\
\text { Exiger Le Règlement Par La Direction Des } \\
\text { Augmentations De Salaire Convenues Le } 3 \\
\text { Mai 2014. }\end{array}$ \\
\hline $\begin{array}{l}\text { Leader In The International Solidarity } \\
\text { Campaign To } \\
\text { Protect Aviation Standards In South } \\
\text { America, His Detention Was Made While } \\
\text { He Was Distributing Information In The } \\
\text { Jorge Chavez Airport In Lima And } \\
\text { Answering Questions From Passengers } \\
\text { About The Upcoming Industrial Actions } \\
\text { And Strikes In LAN And TAM Airlines. } \\
\text { (P.65) }\end{array}$ & $\begin{array}{l}\text { Dirigeant De La Campagne De Solidarité } \\
\text { Internationale Pour Protéger Les Normes } \\
\text { De L'aviation En Amérique Du Sud, Il A } \\
\text { Eté Arrêté Alors Qu'il Distribuait Des } \\
\text { Brochures D'information A L'aéroport } \\
\text { Jorge Chavez A Lima Et Qu'il Répondait } \\
\text { Aux Questions Posées Par Les } \\
\text { Passagers Au Sujet Des Prochaines } \\
\text { Mobilisations Et Grèves Dans Les } \\
\text { Compagnies LAN Et TAM Airlines. (P.68) }\end{array}$ \\
\hline $\begin{array}{l}\text { In Korea, Labour Leaders And Activists } \\
\text { Are In Prison For Engaging In Industrial } \\
\text { Action That Would Be Legal Elsewhere In } \\
\text { The World. (P.69) }\end{array}$ & $\begin{array}{l}\text { En Corée, Des Dirigeant(E)S Syndicaux Et } \\
\text { Des Militants Sont En Prison Pour Avoir } \\
\text { Pris Part A Une Action Revendicative Qui } \\
\text { Serait Considérée Légale Dans D'autres } \\
\text { Pays Du Monde. (P.71) }\end{array}$ \\
\hline $\begin{array}{l}\text { Tripartite Agreement Signed Addressing } \\
\text { Breaches Of ILO Convention 87: On } 25 \\
\text { March 2015, The Minister For } \\
\text { Employment, Productivity \& Industrial } \\
\text { Relations, Jioji K. Konrote, The Chief } \\
\text { Executive Of Fiji's Commerce \& } \\
\text { Employers Federation, Nesbitt D. F. }\end{array}$ & $\begin{array}{l}\text { Signature D'un Accord Tripartite Visant A } \\
\text { Faire Respecter La Convention N N } 87 \text { De } \\
\text { L'oit: Le 25 Mars 2015, Le Ministre De } \\
\text { l'Emploi, De La Productivité Et Des } \\
\text { Relations De Travail, Jioji K. Konrote, Le } \\
\text { Directeur Général De La Fiji Commerce \& } \\
\text { Employers Federation (Federation Du }\end{array}$ \\
\hline
\end{tabular}




\begin{tabular}{|c|c|}
\hline $\begin{array}{l}\text { Hazelman, And General-Secretary Of Fiji's } \\
\text { Trade Union Congress, Felix Anthony } \\
\text { Signed An Agreement To Use The } \\
\text { Employment Relations Promulgation } \\
\text { (ERP) As The Primary Basis For Labour } \\
\text { Management Relations In The } \\
\text { Country.(P.72) }\end{array}$ & $\begin{array}{l}\text { Commerce Et Des Employeurs De Fidji), } \\
\text { Nesbitt D. F. Hazelman, Ainsi Que Le } \\
\text { Secrétaire Général Du } \\
\text { Fiji Trade Union Congress (Confederation } \\
\text { Des Syndicats De Fidji), Felix Anthony, } \\
\text { Ont Signe Un Accord Afin Que Le Texte } \\
\text { Employment Relations Promulgation } \\
\text { (Promulgation Sur Les Relations D'emploi } \\
\text { - ERP) Serve De Base Aux Relations De } \\
\text { Travail Dans Le Pays. (P.77) }\end{array}$ \\
\hline $\begin{array}{l}\text { The Protest Was Attended By Industrial } \\
\text { Workers, Political And Social Activists As } \\
\text { Well As Students. (P.76) }\end{array}$ & $\begin{array}{l}\text { Des Travailleurs/Euses Du Secteur, Des } \\
\text { Militant(E)S Politiques Et Sociaux, Ainsi } \\
\text { Que Des Etudiant(E)S, Ont Participé A La } \\
\text { Manifestation. (P.79) }\end{array}$ \\
\hline $\begin{array}{l}\text { "There Is Increasing Repression Of Trade } \\
\text { Unions Nationwide, Especially Of Unions } \\
\text { Who Are Steadfast In Supporting Workers } \\
\text { And Unwilling To Bend Their Principles } \\
\text { To Submit To Fake } \\
\text { "Industrial Peace" Where The Welfare Of } \\
\text { Capitalists Are Prioritised Over That Of } \\
\text { The Workers," Said Basilio. (P.77) }\end{array}$ & $\begin{array}{l}\text { Les Syndicats Subissent Une Répression } \\
\text { De Plus En Plus Forte Dans Tout Le Pays, } \\
\text { En Particulier Les Syndicats Qui Restent } \\
\text { Fermement Résolus A Soutenir Les } \\
\text { Travailleurs Et A Refuser De } \\
\text { Se Soumettre A Un Simulacre De «Paix } \\
\text { Sociale», Ou Le Bien-Etre Des Capitalistes } \\
\text { Passe Avant Celui Des Travailleurs, } \\
\text { Déclare Basilio. (P.80) }\end{array}$ \\
\hline $\begin{array}{l}\text { Already In } 2010 \text { Deva Used A Range Of } \\
\text { Union Busting Tactics To Dismantle A 40- } \\
\text { Year Industrial Relations System At Plants } \\
\text { In The Cerkezkoy, Kartepe And The } \\
\text { Topkap1 Area Of Istanbul. (P.84) }\end{array}$ & $\begin{array}{l}\text { Deja En 2010, Deva Avait Eu Recours A } \\
\text { Une Série De Manœuvres Antisyndicales } \\
\text { Pour Démanteler Un Système De Dialogue } \\
\text { Social Etabli Depuis Plus } \\
\text { De } 40 \text { Ans Dans Des Entreprises Basées } \\
\text { Dans Les Quartiers De Cerkezkoy, Kartepe } \\
\text { Et Topkap1, A Istanbul. (P.90) }\end{array}$ \\
\hline
\end{tabular}

In These Contexts, The Word 'Industrial' Has Contracted Syntagmatic Relations With Other Words And Has Contributed To The Meanings Of The Syntagms Such As "Industrial Court, Industrial Relations, Industrial Peace, Industrial Relations System, Industrial Workers, Industrial Action, Industrial Company.,

About The Contribution Of Words To The Meanings Of More Complex Units, Cruse (1986: 9) Stresses That:

"As A Matter Of Fact, There Is No Reason Why Language Users Should Be Especially Attuned To The Semantic Properties Of Words. We Do Not Communicate With Isolated Words; Words Are Not The Bearers Of Messages; They Do Not, Of Themselves, 'Make Sense'; They Cannot, Taken Singly, Be True Or False... Words Contribute, Via Their Own Semantic Properties, To The Meanings Of More Complex Units, But Individually They Do Not Occasion Our Most Vivid And Direct Experiences Of Language."'

In The Oxford Advanced Learner's Dictionary, There Are Entries Such As Industrial Action, Industrial Relations, Industrial Tribunal, Industrial Arts, Industrial Estate. An Industrial Action Is An Action That Workers Take, Especially Stopping Work, To Protest To Their Employers About Something. Industrial Relations Are Relations Between Employers And Employees. An Industrial Tribunal Is A Type Of Court That Can Decide On Disputes Between Employers And Employees.

It Is Obvious That In The Context Of The World Of Work, The Word 'Industrial' Refers Not Only To Industries But Also To Workers And Employers. This Second Meaning Is Made Clearer In Most Of The Syntagms In Which The Word 'Industrial' Is Found.

It Is Worth Pointing Out That The Syntagms Such As Industrial Worker, Industrial Relations System And Industrial Peace Are Not Entered In The Dictionary. Industrial Worker Is Translated By Travailleur Du Secteur In French. Where Does The Term Secteur Come From? There Is No Mention Of The Word 'Sector' In The Definition Of 'Industrial'. It Seems That An Industrial Worker (Travailleur Du Secteur) Is Actually A Worker Of An Industry, I. E. Secteur D'activité (Termium). It Was Said Earlier That Industrial Relations (Relations De Travail) Are Relations Between Workers And Employers But Why Is 'Industrial Relations System' Translated By Système De Dialogue Social? Where Does Dialogue Social Come From? The Point Is That The Meaning Of A Syntagm Is Not The Sum Of The Meanings Of The Individual Words That Compose It. The Words That Compose A Syntagm Generate A New Sense That Is Different From The Sense Of The Individual Words. 


\section{CONCLUSION}

In A Nutshell There Is Definitely A Relationship Between Syntagm And Semantics On The One Hand And Context And Semantics On The Other Hand. What Does The Verb 'To Consider' Mean In The Context Of The Aviation Industry? It Does Not Have Only One Meaning. Its Meaning Depends On The Syntagm To Which It Is Attached. The Context Also Influences Word Meaning. So Far It Has Been Shown That Some Words Are Equivalents Of Other Words In Some Contexts But In Other Contexts They Are Not. A Word May Have Five Or More Equivalents But These Are Not Interchangeable In All Situations. In Fact A Word Shares Some Semantic Properties With Other Words. Neither A Dictionary Nor A Thesaurus Can Adequately Present Two Words That Are Equivalent. Their Approach Can Be Misleading Because They Do Not Present Words In Various Contexts. For Example, If I Read In A Dictionary Or A Thesaurus That 'To Demand' Is An Equivalent Of 'Faire Valoir', How Do I Know That The Equivalence Between These Two Terms Is Limited To One Or Two Contexts, Especially If I Am Learning Either Of The Two Languages? In Fact Demand And Faire Valoir Share Some Semantic Properties But They Are Two Different Concepts. This Realisation Will Pave The Way For Further Explorations In The Fields Of Conceptology And Terminology.

\section{REFERENCES}

Journal Papers:

[1] M. Chevalier, P. Isabelle, F. Labelle, C. Lainé, La Traductologie Appliquée A La Traduction Automatique, Meta (Translators' Journal), Vol. 26, N²1. Les Presses De l’Université De Montréal, 1981.

[2] B. Harris, «La Traductologie, La Traduction Naturelle, La Traduction Automatique Et La Sémantique », In Cahier De Linguistique N² 2, Les Presses De l’Université Du Québec, Montréal, 1973Books

[3] B. T. Atkins, A. Duval, R. Milne, Collins Robert French Dictionary (Paris, 1991).

[4] J.C. Catford, A Linguistic Theory Of Translation (Oxford University Press, 1965).

[5] D.A. Cruse, Lexical Semantics (CUP, Cambridge, 1986).

[6] M.A.K. Halliday, W. Teubert, C. Yallop, A., Cermakova, Lexicology And Corpus Linguistics (MPG Books Ltd, Bodmin, Cornwall, 2004).

[7] G. Mounin, Les Problèmes Théoriques De La Traduction (Paris, Gallimard, 1963).

[8] ITUC, Global Rights Index (2015, Www.Ituc-Csi.Org)

[9] J. Saeed, Semantics (Wiley-Blackwell, A John Wiley \& Sons, Ltd., Publication, United Kingdom, 2009).

[10] Vinay, J.-P. Darbelnet, Stylistique Comparée Du Français Et De L’anglais (Paris, Didier, 1958).

[11] S. Wehmeier, Oxford Advanced Learner's Dictionary (Oxford University Press, 2000).

[12] Proceedings Papers:P. Hanks, 'Do Word Meanings Exist?', Computers And The Humanities, Originally Given As A Talk At The First SENSEVAL Workshop, Held At Herstmonceux Castle, Sussex, England On 2-4 September 1998CD Rom

[13] Termium, Version 1.0 Build 8a (Bureau De La Traduction, Travaux Publics Et Services Gouvernementaux, Canada, 2001) 